\title{
Effects of Organic and Inorganic Fertilizers on Growth and Nutrient Uptake by Young Cacao (Theobroma cacao L.)
}

\author{
Jerome A. Dogbatse $\mathbb{D}^{\mathrm{D}}$, Alfred Arthur, Godfred K. Awudzi, Amos K. Quaye, \\ Sampson Konlan, and Andrews A. Amaning
}

Cocoa Research Institute of Ghana, P.O. Box 8, Eastern Region, Tafo-Akim, Ghana

Correspondence should be addressed to Jerome A. Dogbatse; agbesi2000@gmail.com

Received 6 January 2021; Revised 28 February 2021; Accepted 10 March 2021; Published 19 March 2021

Academic Editor: Maria Serrano

Copyright (C) 2021 Jerome A. Dogbatse et al. This is an open access article distributed under the Creative Commons Attribution License, which permits unrestricted use, distribution, and reproduction in any medium, provided the original work is properly cited.

\begin{abstract}
Sustainable cacao cultivation in Ghana has been seriously hampered by high seedling mortality due to the low soil fertility of lands used for the establishment of new cacao farms. Alleviating the low soil fertility to enhance sustainable cacao cultivation requires the use of fertilizers. A study was therefore conducted at the Cocoa Research Institute of Ghana to determine the effect of integrated application of poultry manure (PM) and sulphate of ammonia (SOA) fertilizers on survival, growth, and nutrient uptake by cacao seedlings under marginal field conditions. A randomized complete block design with four replications was used to evaluate the effects of six treatments. Traits assessed were percentage survival, height, trunk cross-sectional area (TCSA), and nutrient uptake. Results from the study showed no significant differences in soil N and $\mathrm{K}$ among the treatments. PM-amended plots had significantly higher soil P than nonamended control and SOA alone. Seedling survival rate ranged from 73.3 to $89.3 \%$ with a higher proportion of surviving plants in PM amended soils. The application of PM alone and its combination with SOA improved growth. Cacao trees of T4 (75\% recommended dosage of SOA + PM) had the largest TCSA increment, which was significantly different from the other soil treatments. Leaf nutrient concentrations in cacao of T4 were higher than the other soil treatments. It was therefore concluded that $\mathrm{T} 4$ could be used during cacao establishment in marginal areas for improved plant survival and growth.
\end{abstract}

\section{Introduction}

Cacao (Theobroma cacao L.) is an important cash crop that provides enormous foreign exchange about US $\$ 2.5$ billion per annum for Ghana and remains the mainstay of the national economy [1]. Cacao cultivation is a major source of livelihood for over a million farmers and their dependants in rural communities of Ghana and contributes actively to the economy of these communities [2]. Attempts by farmers to increase cacao production are currently achieved through the establishment of new farms and the rehabilitation of aged/unproductive farms with mixed hybrid seedlings. For the past seven years, the Government of Ghana through Ghana Cocoa Board (COCOBOD) has been supplying farmers with millions of cacao seedlings generated from improved varieties to establish new farms or rehabilitate old cacao farms. However, published statistics on cacao seedling survival rates from farmers' fields are difficult to obtain. Therefore, anecdotal evidence on the millions of seedlings supplied annually to farmers suggests a high mortality rate in their fields [3].

The high mortality rate that results in suboptimal plant population densities is partly attributed to marginal field conditions like inadequate soil nutrients and irregular rainfall. Low soil fertility has been noted as one of the field establishment stresses affecting cacao within the first year after transplanting $[4,5]$. The establishment of cacao farms in Ghana has traditionally been dependent on the high natural soil nutrient endowment in primary or older secondary forest soils [6]. However, these fertile soils for growing cacao are becoming limited due to competition for the cultivation of other crops. Consequently, many of the tropical soils including the soils used for cacao cultivation are characterized by low activity charges due to either 
inherent low clay content or low soil organic matter and therefore low nutrient binding capacity [7]. Additionally, some of these soils have already been rendered infertile by either continuous cropping with cacao or food crops.

Cacao cultivation on most soils needs an improved regime of nutrient input [7]. Improvement of the soil fertility status of cacao farms in Ghana is critical because cacao trees require enough supply of nutrients for optimal growth and yield $[6,8]$. Cacao farmers in Ghana largely use inorganic fertilizers, particularly sulphate of ammonia (SOA) that is the recommended fertilizer at a rate of $70 \mathrm{~g}$ per young cacao plant [9]. However, the use of inorganic fertilizers to supply the needed amount of nutrients to cacao trees is presently expensive for Ghanaian cacao farmers $[6,8]$. Furthermore, continuous usage of inorganic fertilizers alone affects the soil health resulting in decreased soil productivity [10]. The continuous use of inorganic fertilizers alone in highly weathered soils in the cacao growing areas of Ghana would adversely affect cacao establishment and growth due to the poor physical structure and nutrient retention characteristics of these soils. Organic fertilizers are known to improve the physical properties of the soils, help the soil to maintain better tilth, and increase water holding capacity [11, 12]. Poultry manure (PM) is extensively used by farmers in Ghana due to the expansion of the poultry industry, which has resulted in a tremendous increase in PM. PM has been recommended as organic fertilizer for mature (reproductive) cacao trees at $1,800 \mathrm{~kg} \mathrm{ha}^{-1}$ in Ghana [9], because of its high fertilizing value compared to other types of livestock manure. However, the use of PM in young cacao trees has not been sufficiently explored in Ghana.

Integrated application of organic and inorganic fertilizers in crop production has been reported to increase growth [13] more than either used alone. Similarly, the application of organic fertilizer in combination with inorganic fertilizer has been reported to increase absorption of $\mathrm{N}, \mathrm{P}$, and $\mathrm{K}$ in plants compared to sole application of organic or inorganic fertilizers [14]. Hence, an integrated application of organic and inorganic fertilizers appears to be a suitable technique to meet nutrient requirements of cacao cultivated in marginal soils for improved and sustainable growth. However, the extent to which organic fertilizers like PM could increase the efficiency of applied inorganic fertilizers like SOA to increase the absorption of nutrients and sustainable growth in young cacao plants has not received research attention in Ghana. To evaluate this on sustainable cacao growth, integrated use of PM and SOA fertilizers for cacao cultivation was investigated in a field experiment with young cacao trees on a marginal soil. The research emphasis was to determine the effect of integrated application of PM and SOA fertilizers on plant survival, growth, and nutrient uptake under marginal soil conditions in the early stages of establishment.

\section{Materials and Methods}

2.1. Study Site. The study was situated on an old farm located within the experimental area at Cocoa Research Institute of Ghana (CRIG), New Tafo-Akim (latitude $6^{\circ} 13^{\prime} \mathrm{N}$; longitude $0^{\circ} 21^{\prime} \mathrm{W}$ ), which is approximately $222 \mathrm{~m}$ above the sea level, situated in the humid rainforest belt of the Eastern Region of Ghana. The mean annual rainfall at the location before the study was $1500 \mathrm{~mm}$. The soil of this farm had carried cacao for the past 30 years, which had been grubbed. The soil belongs to the Wacri series [15], which is typical Forest Ochrosols under the Ghanaian system [15] or Ferric Lixisols [16] and brown to yellowish red, well-drained, and developed in situ from weathered materials of hornblende granodiorite [17]. Climatic conditions during the study period were obtained from the CRIG meteorological station (Table 1).

2.2. Plant Material. Mature mixed hybrid cacao pods were derived from manual pollinations of different varieties by the Plant Breeding Division of CRIG and used for raising the cacao seedlings. Seeds were nursed in nursery polyethylene bags measuring $17.5 \times 25 \mathrm{~cm}$ between October 2016 and April 2017.

2.3. Experimental Design and Treatments. A randomized complete block design with four replicates was used for the experiment. Organic fertilizer used was a 2-month-old PM collected from layer birds in a deep litter system after the chickens were removed. The inorganic fertilizer used was SOA. Subsamples of PM used were taken from bulk sample and analysed for chemical properties. In May 2017, after the plants were well established, six treatments (Table 2) consisting of three different SOA-PM combinations, $100 \% \mathrm{PM}$, CRIG recommended dosage of SOA [9], and a nonamended control were applied to the 36 -tree $(6 \times 6$ trees $)$ core plot within a 64 -tree plot $(8 \times 8$ trees) for each treatment. Information about treatments applied to the plots is shown in Table 1 . The plot size was $441 \mathrm{~m}^{2}$ with cacao planted at $3 \times 3 \mathrm{~m}$. The soil amendments (both PM and SOA) were applied once per year. Combined treatments were additive (Table 1). The treatments were ring applied and mixed into the topsoil at the periphery of the lateral root zone of each tree $(0.2-0.5 \mathrm{~m}$ from the tree base).

2.4. Plot Establishment and Husbandry. The plot was planted with plantain in September 2016 at a spacing of $3 \times 3 \mathrm{~m}$ to provide temporary shade to the cacao trees. The temporary shade was augmented by planting stakes of Gliricidia sepium in alternate rows of the plantain to obtain a planting density of $6 \times 6 \mathrm{~m}^{2}$. Additionally, seedlings of Terminalia ivorensis and Terminalia superba were planted at a density of 25 trees per 1 ha as a permanent shade for the duration of the crop. Six-month-old cacao seedlings previously raised in a nursery were transplanted to the field in April 2017 within rows of the plantain at a spacing of $3 \times 3 \mathrm{~m}$ (equivalent to 1,111 plants ha ${ }^{-1}$ ). Two perimeter guard rows were planted around each plot at the same spacing as used for the core plot. Weeds were controlled manually when necessary during the study period to avoid competition with the cacao trees. Application of agro-pesticides followed recommended practices for cacao production in Ghana [9]. 
TABLE 1: Weather characteristics during the period of the study.

\begin{tabular}{lcccc}
\hline Year & Rainfall $(\mathrm{mm})^{1}$ & \multicolumn{2}{c}{ Mean temperature $\left({ }^{\circ} \mathrm{C}\right)$} & Mean relative humidity $(\%)$ \\
& & Min & At $1500 \mathrm{~h}$ \\
\hline $2017^{*}$ & $1,499.1(102)$ & 22.8 & 31.4 & 70.4 \\
2018 & $1,423.7(108)$ & 23.2 & 32.1 & 64.7 \\
$2019^{*}$ & $80.6(8)$ & 24.1 & 34.5 & 55.5 \\
ICCO-SR $^{2}$ & $1500-2000$ & $18-21$ & $30-32$ & $70-80$ \\
\hline
\end{tabular}

${ }^{*} 2017$ and 2019 measurements were from April to December and January to February, respectively, when the last set of data were collected. ${ }^{1}$ Value in parenthesis is the number of rainy days. ${ }^{2} \mathrm{ICCO}-\mathrm{SR}$ is International Cocoa Organization suitable ranges.

TABLE 2: Experimental treatments used in the study.

\begin{tabular}{lc}
\hline Treatment & Description \\
\hline T1 & Nonamended control \\
T2 & Recommended dosage of SOA $\left(70 \mathrm{~g} \mathrm{per} \mathrm{tree} \mathrm{or} 78 \mathrm{~kg} \mathrm{ha}^{-1}\right)^{\dagger}$ \\
T3 & $100 \% \mathrm{PM}^{*}$ \\
T4 & $75 \%$ recommended dosage of SOA $\left(52.5 \mathrm{~g} \mathrm{per} \mathrm{tree} \mathrm{or} 58.5 \mathrm{~kg} \mathrm{ha}^{-1}\right)+25 \% \mathrm{PM}^{*}$ \\
T5 & $50 \%$ recommended dosage of SOA $\left(35 \mathrm{~g} \mathrm{per} \mathrm{tree} \mathrm{or} 39 \mathrm{~kg} \mathrm{ha}^{-1}\right)+50 \% \mathrm{PM}^{*}$ \\
T6 & $25 \%$ recommended dosage of SOA $\left(17.5 \mathrm{~g}\right.$ per tree or $\left.19.5 \mathrm{kgha}^{-1}\right)+75 \% \mathrm{PM}^{*}$ \\
\hline
\end{tabular}

${ }^{\dagger}$ CRIG recommended dosage of SOA for young cacao [9]. ${ }^{*} \mathrm{PM}$ rates in the treatments were calculated based on the $\mathrm{N}$ content of PM (Table 3 ) and the $\mathrm{N}$ supplied by SOA in CRIG recommended dosage for young cacao [9].

2.5. PM and Soil Sampling and Analyses. Prior to the application of treatments in May 2017 and May 2018, PM samples were taken for analyses. Similarly, soil samples were taken for analyses in April 2017 as baseline samples. In each of the PM sampling times (2017 and 2018), a composite sample of approximately $1 \mathrm{~kg}$ was collected from different bags of PM obtained that year and analysed (Table 3). At the soil sampling time (2017), two composite soil samples were collected from two soil depths (surface depth, i.e., $0-15 \mathrm{~cm}$, and subsurface depth, i.e., $15-30 \mathrm{~cm}$ ), critical for cacao nutrition $[18,19]$, where approximately $80 \%$ of cacao tree lateral roots are found [20]. The soil samples were taken from the base of four cacao trees per plot and bulked into polyethylene bags as a composite sample for each depth. The soil samples were then analysed for their physicochemical properties. Particle size analysis was determined by the method of Bouyoucos [21]; soil pH was determined electrometrically in distilled water at $1: 2.5(\mathrm{w} / \mathrm{v})$ soil:water suspension using an electronic $\mathrm{pH}$ meter with a glass electrode [22]. Organic carbon (OC) was determined using the wet combustion method [23]. Total nitrogen (TN) was determined using the Kjeldahl method [24]. Available phosphorus (AP) in soil was determined by Mehlich-3 extraction procedure using $1: 10(\mathrm{w} / \mathrm{v})$ soil : extractant ratio [25] and colourimetrically on a spectrophotometer using ascorbic acid for colour development. Exchangeable basic cations $(\mathrm{K}, \mathrm{Ca}$, and $\mathrm{Mg}$ ) in soil were extracted using ammonium acetate at 1:5(w/v) soil : extractant ratio [26] and analysed by atomic absorption spectrometer. PM samples were also analysed for chemical properties using some of the standard methods used in analysing the baseline soil samples. However, total phosphorus was determined by double acid wet digestion method using $2: 1(\mathrm{v} / \mathrm{v})$ nitric : perchloric acids ratio [27] and colourimetrically on spectrophotometer, and total $\mathrm{K}, \mathrm{Mg}$, and $\mathrm{Ca}$ were determined by double acid wet digestion method using 2:1 (v/v) nitric:perchloric acids ratio [27], followed by atomic absorption spectrometry.

Following soil amendment in May 2017 and May 2018, at the end of the study, soil samples were collected in January 2019 (22 months after transplanting cacao seedlings) from each treated plot and evaluated. Two soil subsamples were collected from the outer edge of the root zone $(20-50 \mathrm{~cm}$ from the tree base) in the centre of two of the four replicate plots for each treatment. The samples were collected from two depths $(0-15$ and $15-30 \mathrm{~cm})$ by first removing approximately $1 \mathrm{~cm}$ of loose soil and other surface materials. The four subsamples were combined and thoroughly mixed, and then a composite sample of about $1 \mathrm{~kg}$ per treatment was taken for each depth. The soil samples were subsequently analysed using the standard methods described in the analyses of the baseline soil samples.

2.6. Cacao Leaf Sampling and Analyses. Prior to the application of treatments in May 2017, baseline cacao leaf samples were collected two weeks after transplanting in April 2017 from the same plots from which baseline soil samples were taken. These baseline leaf samples were 3-4 fully expanded mature cacao leaves collected from the middle of the selected branches on each of the four central plants for subsequent analyses. Additionally, at the end of the study, cacao leaf samples were taken in January 2019 by collecting 3-4 fully expanded mature leaves from selected branches on each of the same four central plants. Cacao leaf samples taken in April 2017 (baseline leaf samples) and January 2019 (end of study leaf samples) were oven-dried at $75^{\circ} \mathrm{C}$ for 72 hours to attain constant weight and were ground into a fine powder using a stainless mill. TN in leaves was determined using the Kjeldahl method [24]. Total phosphorus (TP) was determined by double acid wet digestion method using $2: 1(\mathrm{v} / \mathrm{v})$ 
TABLE 3: Some chemical properties of the poultry manure used as amendment.

\begin{tabular}{lcc}
\hline Chemical property & & Level (concentration) \\
\hline $\mathrm{OC}(\%)$ & 2017 & 2018 \\
$\mathrm{TN}\left(\mathrm{mg} \mathrm{kg}^{-1}\right)$ & 2.5 & 2.1 \\
$\mathrm{C} / \mathrm{N}$ & 27 & 24 \\
$\mathrm{pH}\left(\mathrm{H}_{2} \mathrm{O}\right)$ & 0.9 & 0.9 \\
$\mathrm{TP}\left(\mathrm{mg} \mathrm{kg}^{-1}\right)$ & 6.6 & 6.9 \\
$\mathrm{~K}\left(\mathrm{mg} \mathrm{kg} \mathrm{k}^{-1}\right)$ & 502.6 & 490.7 \\
$\mathrm{Mg}\left(\mathrm{mg} \mathrm{kg}^{-1}\right)$ & 58.9 & 45.6 \\
$\mathrm{Ca}\left(\mathrm{mg} \mathrm{kg}^{-1}\right)$ & 12.8 & 13.2 \\
\end{tabular}

nitric : perchloric acids ratio [27] and colourimetrically on a spectrophotometer using ascorbic acid for colour development. Potassium, $\mathrm{Mg}$, and $\mathrm{Ca}$ in leaves were also determined by double acid wet digestion method using $2: 1(\mathrm{v} / \mathrm{v})$ nitric: perchloric acids ratio [27], followed by atomic absorption spectrometry.

2.7. Growth Data. The traits evaluated with respect to growth were plant height, stem diameter, and percentage seedling survival. These growth data were taken on 16 core cacao plants within the 36-tree core plot for each treatment that is replicated four times. One month after transplanting and prior to the commencement of treatment application in May 2017, height of each seedling was measured with a meter rule from the soil surface to the apex of the plant. Stem diameter at a height of $10 \mathrm{~cm}$ from the soil surface was measured with digital callipers. Subsequent seedling height and stem diameter measurements were taken at six-month interval until February 2019, following the same procedures. The trunk cross-sectional area (TCSA) was estimated from the stem diameter measurements using

$$
\operatorname{TCSA}=\pi \frac{d^{2}}{4}
$$

where $d$ denotes the stem diameter.

The increase in TCSA for a seedling was taken as the difference between the final and initial TCSA estimates.

Percentage seedling survival was assessed by counting the number of plants alive per plot in February of the year after transplanting (at the end of the main dry season). The survival rate was then calculated using

$$
S_{\text {rate }}(\%)=\frac{P_{s}}{T_{s}} \times 100,
$$

where $S_{\text {rate }}$ is the survival rate; $P_{s}$ is the number of plants surviving; and $T_{s}$ is the total number of seedlings transplanted.

2.8. Statistical Analysis. Data analysis in this study was performed using the GenStat statistical software (Lawes Agricultural Trust, Rothamsted Experimental Station). Growth and soil data collected were subjected to analysis of variance. Treatment means were compared using the standard error of difference (SED); otherwise, the Tukey post hoc test was used.

\section{Results and Discussion}

Currently, new cacao farms in Ghana are established on lands that have been previously cropped with food crops or moribund cacao and grubbed without fallowing. Soils of such lands are depleted of nutrients because of continuous nutrient mining due to nutrient outflow through cocoa beans and pod husks that are later harvested $[28,29]$. Reduced soil fertility together with low amounts of rainfall has contributed to a decline in the productivity of cacao in Ghana. Although the benefits of the sole application of organic or inorganic fertilizers in cacao production are well known, cacao production on most Ghanaian soils needs an improved regime of nutrient input; thus, an integrated approach of combining both forms of fertilizers for sustainable cacao production is discussed.

3.1. Weather Characteristics. Data on weather characteristics during the study were obtained from CRIG meteorological station, located approximately $1 \mathrm{~km}$ from the study site. Some characteristics of the prevailing weather conditions during the experimental period, from field transplanting in April 2017 to the end of the study period in February 2019, are shown in Table 1 . The total annual rainfall received in 2017 and 2018 was below the suitable range of 1500-2000 mm required for cacao. Generally, there was a pronounced dry season between November and February during the period of the experiment. This can be attributed to the low relative humidity levels generally below the suitable range of $70-80 \%$ for cacao. The mean minimum and maximum temperatures recorded during the period of the experiment were $22.8^{\circ} \mathrm{C}$ and $34.5^{\circ} \mathrm{C}$, respectively (Table 1 ). Relative humidity during the period ranged from 55.5 to $70.4 \%$ at $1500 \mathrm{~h}$ GMT, which was above International Cocoa Organization suitable ranges for only 2017.

3.2. Soil Properties. Baseline or initial soil properties determined on the experimental site in 2017, prior to establishing the study, indicated that the soil texture was generally fine through the entire depths sampled (Table 4). Both surface depth $(0-15 \mathrm{~cm})$ and subsurface depth $(15-30 \mathrm{~cm})$ had a relatively high sand content, that is, $58.4 \%$ and $55.2 \%$, respectively. The textural class of the soil was sandy clay loam for both horizons. 
The average soil $\mathrm{pH}$ for both depths was below the critical minimum for cacao growth. The low soil OC and exchangeable concentrations of basic cations especially $\mathrm{Ca}$ which is below the critical minimum could be attributed in part to the marked soil acidity at the experimental site, indicated by the acidic nature of the soil (Table 4). The average OC contents for both depths were far below the critical minimum of $3.5 \%$ reported to be ideal for cacao cultivation [6]. Average $\mathrm{TN}$ in the surface horizons was above the critical minimum of $0.09 \%$, whereas that of subsurface depth was equal to the critical minimum. The average available $\mathrm{P}$ for both depths was far below the critical minimum of $20 \mathrm{mg} \mathrm{kg}^{-1}$ considered suitable for cacao cultivation. The average exchangeable $\mathrm{K}$ and exchangeable $\mathrm{Mg}$ for both depths were above their critical minimum values considered adequate for cacao cultivation, that is, 0.25 $\mathrm{cmol}_{\mathrm{c}} \mathrm{kg}^{-1}$ and $1.33 \mathrm{cmol}_{\mathrm{c}} \mathrm{kg}^{-1}$, respectively (Table 4). However, the average exchangeable $\mathrm{Ca}$ at both depths was far below the critical minimum of $7.50 \mathrm{cmol}_{\mathrm{c}} \mathrm{kg}^{-1}$.

Analyses of soil samples taken to at end of the study showed that soil $\mathrm{pH}$ for both depths was higher than the critical minimum of 5.6 for cacao growth (Table 5) except for nonamended control (T1). This indicates that the amounts of soil amendments were enough to affect soil $\mathrm{pH}$. Also, the increase in soil $\mathrm{pH}$ implies decreasing availability of toxic acidic cations like monomeric $\mathrm{Al}$ species which in tropical soils like the soils used for the study has been reported to be toxic to plants $[30,31]$.

Average clay content was high at both depths (>31\%), while silt content was relatively low $(<13 \%)$ (Table 4$)$. The soil data from the nonamended control (Table 5) confirm the baseline data in Table 4, particularly the critically low $\mathrm{OC}, \mathrm{AP}$, and $\mathrm{Ca}$ contents and low soil $\mathrm{pH}$. Soil $\mathrm{pH}$ was higher in the plots amended with PM alone (T3) than the plots amended with SOA alone (T2) (Table 5). The applied PM had a relatively high pH of 6.6 (Table 3); therefore, soil $\mathrm{pH}$ readings in the $\mathrm{PM}$ amended soils were higher than in nonamended control (T1) and SOA alone (T2) soils indicating that the amounts of PM applied were enough to affect soil $\mathrm{pH}$. The addition of organic matter has been reported to increase soil $\mathrm{pH}$ by enhancing processes of ammonification, binding of acidic cations such as $\mathrm{Al}$ species, and decarboxylation [32]. Hence, an important effect of the applied PM as stand alone or in combination with SOA on increasing the soil pH (Table 5) may be due to mineralization of PM [31] and decreasing availability of toxic acidic cations like $\mathrm{Fe}$ and $\mathrm{Al}$ in soil solution due to chelation effect of organic molecules [32]. Additionally, the high average exchangeable bases, especially $\mathrm{K}$ concentration of the applied PM, may partly account for an increased soil $\mathrm{pH}$, twenty-two months after organic amendment (Table 5). The soil concentration of OC was not influenced by the soil treatments as there were no significant differences between the treatments. Generally, amendment with PM alone and PM plus SOA fertilizer significantly increased soil OC content in the surface depths compared to the subsurface depths (Table 5). However, the levels remained well below the estimated adequate levels of $3.5 \%$ recommended for cacao [6].
The soil organic C contents of nonamended control (T1) and all amended soils for both depths increased slightly (Table 5), but levels remained below the critical minimum of $3.5 \%$, which were reported to be suitable for cacao cultivation [6]. The increase in organic $\mathrm{C}$ in nonamended control might be because of the decomposition of cacao and other plant litters in the soil.

Concentrations of soil $\mathrm{N}$ were adequate at both depths as it was higher than the critical minimum of $0.09 \%$, suggesting that the supply of these nutrients in the soil was not limiting (Table 5). There were no significant differences in soil $\mathrm{N}$ among the treatments. This indicates that the amendments had little effect on soil $\mathrm{N}$, which was probably rapidly taken up by the cacao trees or else leached and/or volatilised. However, the sole SOA fertilizer treatment had elevated $\mathrm{N}$ levels at both depths compared to PM alone and PM plus SOA and the nonamended control (Table 5). The results showed that the soil TN content of both depths increased at the end of the study (Tables 4 and 5). The presence of cacao plant through its litter mineralization has resulted in improved soil $\mathrm{N}$. Decreasing the SOA content of the treatments led to a linear decrease in soil nitrogen content at both depths. The highest and the least soil $\mathrm{N}$ content were observed in samples from T2 and T6, respectively.

Soil $\mathrm{P}$ concentrations were adequate above the critical minimum of $20 \mathrm{mg} \mathrm{kg}^{-1}$, suggesting that the supply of these nutrients in the soil was not limiting (Table 5). Apart from T5, all PM and PM plus SOA fertilizer-amended plots had significantly higher $(p<0.05)$ soil $\mathrm{P}$ than the nonamended control (T1) and SOA alone (T2). The results showed that the application of either PM alone or in combination with SOA except for T5 resulted in higher soil AP content compared to $\mathrm{T} 1$ and T2. This is due to the presence of PM in the treatments which increased the availability of $\mathrm{P}$, either through the mineralization of organic $\mathrm{P}$ in the $\mathrm{PM}$, thereby increasing the soil AP content, or due to the inactivation of oxides and hydroxides of iron and aluminium commonly found in the soils used for the experiment, thereby reducing the P-fixation in the soil. This agrees with the report that there is a marked increase in the AP content of the soil with the application of farmyard manure due to the reduction of P-fixation in soil [33].

Generally, exchangeable bases ( $\mathrm{K}, \mathrm{Mg}$, and $\mathrm{Ca}$ ) were high at the experimental site after treatment application, even though Ca was critically low. Soil K concentrations of the treatments were not significantly different. A study also reported that the application of manure and its integration with chemical fertilizer had no significant effect on soil exchangeable $\mathrm{K}$ content [34]. Exchangeable $\mathrm{K}$ contents in both depths were lower than the critical minimum of 0.25 $\mathrm{cmol}_{\mathrm{c}} \mathrm{kg}^{-1}$. However, $\mathrm{K}$ concentrations were significantly higher in the surface depth than the subsurface depth for the treatments. Exchangeable Ca contents in both depths were lower than critical minimum of $7.50 \mathrm{cmol}_{\mathrm{c}} \mathrm{kg}^{-1}$; however, exchangeable $\mathrm{Mg}$ for both depths was above their critical minimum $\left(1.33 \mathrm{cmol}_{\mathrm{c}} \mathrm{kg}^{-1}\right)$ considered adequate for cacao cultivation [6]. Soil $\mathrm{Mg}$ and $\mathrm{Ca}$ concentrations of the treatments were significantly different $(p<0.05)$ between the 
TABLE 4: Soil nutrient contents and other soil properties in $0-15 \mathrm{~cm}$ depth and $15-30 \mathrm{~cm}$ depth at the study site in 2017 (prior to treatment application).

\begin{tabular}{|c|c|c|c|}
\hline \multirow{2}{*}{ Soil property } & \multicolumn{2}{|c|}{ Depth $(\mathrm{cm})$} & \multirow{2}{*}{ Critical minimum ${ }^{*}$} \\
\hline & $0-15$ & $15-30$ & \\
\hline Sand/clay/silt (\%) & $58.4 / 31.6 / 10$ & $55.2 / 32.8 / 12$ & \\
\hline OC $(\%)$ & 1.2 & 0.9 & 3.5 \\
\hline TN (\%) & 0.12 & 0.09 & 0.09 \\
\hline $\mathrm{C} / \mathrm{N}$ & 10 & 10 & \\
\hline $\mathrm{pH}\left(\mathrm{H}_{2} \mathrm{O}\right)$ & 5.31 & 5.11 & 5.60 \\
\hline $\mathrm{AP}\left(\mathrm{mg} \mathrm{kg}^{-1}\right)$ & 5.24 & 3.33 & 20.00 \\
\hline $\mathrm{K}\left(\mathrm{cmol}_{\mathrm{c}} \mathrm{kg}^{-1}\right)$ & 0.36 & 0.32 & 0.25 \\
\hline $\mathrm{Mg}\left(\mathrm{cmol}_{\mathrm{c}} \mathrm{kg}^{-1}\right)$ & 2.21 & 1.64 & 1.33 \\
\hline $\mathrm{Ca}\left(\mathrm{cmol}_{\mathrm{c}} \mathrm{kg}^{-1}\right)$ & 5.26 & 4.49 & 7.50 \\
\hline
\end{tabular}

${ }^{*}$ Critical minimum of nutrients required by cacao [6].

TABLE 5: Effect of soil amendments on soil $\mathrm{pH}$ and nutrients at two depths after two successive years of treatment application.

\begin{tabular}{|c|c|c|c|c|c|c|c|c|}
\hline \multirow[t]{2}{*}{ Treatment } & $\mathrm{PH}$ & OC & $\mathrm{TN}$ & $\mathrm{C} / \mathrm{N}$ & ${ }_{-1}^{\mathrm{AP}}$ & $\mathrm{K}$ & $\begin{array}{c}\mathrm{Mg} \\
\left(\mathrm{cmol}_{\mathrm{c}} \mathrm{kg}^{-1}\right)\end{array}$ & $\mathrm{Ca}$ \\
\hline & \multicolumn{8}{|c|}{ Depth $(0-15 \mathrm{~cm})$} \\
\hline $\mathrm{T} 1$ & $5.41^{\mathrm{a}}$ & $1.73^{\mathrm{a}}$ & $0.18^{\mathrm{a}}$ & $9.6^{\mathrm{a}}$ & $34.10^{\mathrm{c}}$ & $0.14^{\mathrm{a}}$ & $2.04^{\mathrm{a}}$ & $4.50^{b c}$ \\
\hline $\mathrm{T} 2$ & $6.09^{\mathrm{a}}$ & $2.06^{\mathrm{a}}$ & $0.20^{\mathrm{a}}$ & $10.3^{\mathrm{a}}$ & $24.58^{\mathrm{d}}$ & $0.27^{\mathrm{a}}$ & $2.13^{\mathrm{a}}$ & $5.11^{b c}$ \\
\hline T3 & $6.74^{\mathrm{a}}$ & $1.76^{\mathrm{a}}$ & $0.18^{\mathrm{a}}$ & $9.8^{\mathrm{a}}$ & $85.34^{\mathrm{a}}$ & $0.30^{\mathrm{a}}$ & $2.16^{\mathrm{a}}$ & $6.16^{\mathrm{a}}$ \\
\hline $\mathrm{T} 4$ & $6.38^{\mathrm{a}}$ & $1.72^{\mathrm{a}}$ & $0.18^{\mathrm{a}}$ & $9.6^{\mathrm{a}}$ & $52.76^{\mathrm{b}}$ & $0.18^{\mathrm{a}}$ & $2.04^{\mathrm{a}}$ & $4.21^{\mathrm{c}}$ \\
\hline T5 & $6.26^{\mathrm{a}}$ & $1.64^{\mathrm{a}}$ & $0.17^{\mathrm{a}}$ & $9.6^{\mathrm{a}}$ & $22.97^{\mathrm{d}}$ & $0.22^{\mathrm{a}}$ & $1.70^{\mathrm{a}}$ & $4.55^{b c}$ \\
\hline T6 & $6.34^{\mathrm{a}}$ & $1.55^{\mathrm{a}}$ & $0.16^{\mathrm{a}}$ & $9.7^{\mathrm{a}}$ & $49.86^{\mathrm{b}}$ & $0.32^{\mathrm{a}}$ & $2.02^{\mathrm{a}}$ & $5.31^{\mathrm{ab}}$ \\
\hline & Depth $(15-30 \mathrm{~cm})$ & & & & & & & \\
\hline $\mathrm{T} 1$ & $5.52^{\mathrm{c}}$ & $1.16^{\mathrm{a}}$ & $0.11^{\mathrm{a}}$ & $10.5^{\mathrm{a}}$ & $20.11^{\mathrm{cd}}$ & $0.13^{\mathrm{a}}$ & $1.33^{\mathrm{a}}$ & $4.54^{\mathrm{c}}$ \\
\hline $\mathrm{T} 2$ & $6.26^{\mathrm{abc}}$ & $1.43^{\mathrm{a}}$ & $0.14^{\mathrm{a}}$ & $10.2^{\mathrm{a}}$ & $14.75^{\mathrm{d}}$ & $0.21^{\mathrm{a}}$ & $1.45^{\mathrm{a}}$ & $5.01^{\mathrm{b}}$ \\
\hline T3 & $7.01^{\mathrm{a}}$ & $1.36^{\mathrm{a}}$ & $0.13^{\mathrm{a}}$ & $10.5^{\mathrm{a}}$ & $64.29^{\mathrm{a}}$ & $0.19^{\mathrm{a}}$ & $1.74^{\mathrm{a}}$ & $5.89^{\mathrm{a}}$ \\
\hline $\mathrm{T} 4$ & $6.90^{\mathrm{a}}$ & $1.26^{\mathrm{a}}$ & $0.13^{\mathrm{a}}$ & $9.7^{\mathrm{a}}$ & $25.91^{b}$ & $0.13^{\mathrm{a}}$ & $1.39^{\mathrm{a}}$ & $4.88^{b c}$ \\
\hline T5 & $6.46^{\mathrm{ab}}$ & $1.25^{\mathrm{a}}$ & $0.12^{\mathrm{a}}$ & $10.4^{\mathrm{a}}$ & $16.63^{\mathrm{d}}$ & $0.16^{\mathrm{a}}$ & $1.25^{\mathrm{a}}$ & $4.00^{\mathrm{d}}$ \\
\hline T6 & $6.12^{b c}$ & $1.16^{\mathrm{a}}$ & $0.12^{\mathrm{a}}$ & $9.7^{\mathrm{a}}$ & $22.82^{b c}$ & $0.18^{\mathrm{a}}$ & $1.46^{\mathrm{a}}$ & $4.14^{\mathrm{d}}$ \\
\hline Crit min* & 5.60 & 3.5 & 0.09 & - & 20.00 & 0.25 & 1.33 & 7.50 \\
\hline SE Trmt & 0.16 & 0.11 & 0.08 & 0.16 & 1.06 & 0.04 & 0.09 & 0.11 \\
\hline SE Dep & 0.09 & 0.07 & 0.05 & 0.09 & 0.61 & 0.02 & 0.05 & 0.06 \\
\hline SED Trmt & 0.23 & 0.16 & 0.12 & 0.22 & 1.50 & 0.05 & 0.13 & 0.15 \\
\hline SED Dep & 0.13 & 0.09 & 0.07 & 0.13 & 0.87 & 0.03 & 0.07 & 0.09 \\
\hline
\end{tabular}

${ }^{*}$ Crit min $=$ critical minimum of nutrients required by cacao [6]. SE $=$ standard errors. SED $=$ standard errors of differences. Trmt $=$ treatment. Dep $=$ depth. Within the same column, means followed by different superscript alphabet(s) are significantly different at $\mathrm{p}<0.05$ using Tukey's post hoc test.

treatments with $\mathrm{T} 3$ (PM alone) recording significantly higher $\mathrm{Mg}$ and $\mathrm{Ca}$ than the other treatments (Table 5). Similarly, there was a significantly higher soil $\mathrm{Mg}$ and $\mathrm{Ca}$ content in the surface depth than the subsurface depth. The relatively high exchangeable bases in other soil treatments compared to the nonamended control indicate that the treatments chemically improved soils.

3.3. Plant Growth. The percentage of surviving cacao trees at the end of the study period is presented (Table 6). Generally, seedlings showed high survival rates, ranging from 73.3 to $89.3 \%$. Similarly, a higher survival rate of 75.0 to $97.0 \%$ was reported for cacao trees grown in Nigeria [35]. The higher percentage of survival observed in this experiment could be partly attributable to differences in the intensity of weather variables (rainfall, temperature, and humidity) and partly to the soil amendments.
Better rainfall distribution and a higher amount of precipitation during the critical dry months of December to February are important for tree crop seedling survival during establishment $[35,36]$. Among the treatments, soils amended with PM had a higher proportion of surviving plants, indicating a probable adequate nutrient availability due to PM and high soil moisture due to improved moisture holding capacity by the PM. On the other hand, the treatment that had no amendment (T1) had the least proportion of surviving plants (Table 6). Cacao tree deaths in the nonamended control plots may be due to the nutrient deficiency effect, leading to less vigour in these plants. The higher $\mathrm{N}$ content in the plant tissue as shown by the higher leaf $\mathrm{N}$ concentrations (Table 7) especially in PM-treated plots ensured faster cacao tree growth which contributed to high survival [37]. Also, more vigorous cacao trees had a higher survival rate than less vigorous plants under drought stress conditions [38]. This agreed with the observation in 
TABLE 6: Effects of different treatments on plant height, TCSA, and percentage of surviving cacao plants assessed over a period of 22 months after transplanting.

\begin{tabular}{lccc}
\hline Treatments & Plant height $(\mathrm{cm})$ & TCSA $\left(\mathrm{cm}^{2}\right)$ & Survival rate $(\%)$ \\
\hline T1 & $147.8^{\mathrm{bc}}$ & $33.8^{\mathrm{c}}$ & 73.3 \\
T2 & $139.2^{\mathrm{c}}$ & $30.4^{\mathrm{d}}$ & 78.6 \\
T3 & $157.0^{\mathrm{b}}$ & $37.0^{\mathrm{b}}$ & 85.8 \\
T4 & $177.5^{\mathrm{a}}$ & $39.0^{\mathrm{a}}$ & 88.6 \\
T5 & $151.4^{\mathrm{bc}}$ & $34.1^{\mathrm{c}}$ & 75.8 \\
T6 & $149.7^{\mathrm{bc}}$ & $37.5^{\mathrm{b}}$ & 89.3 \\
SE & $8.3^{\mathrm{b}}$ & 0.4 & 0.6 \\
SED & 11.8 & 0.6 & \\
\hline
\end{tabular}

$\mathrm{SE}=$ standard errors; $\mathrm{SED}=$ standard errors of differences. Within the same column, means followed by different superscript alphabet(s) are significantly different at $p<0.05$ using Tukey's post hoc test.

this experiment, as soil treatments that resulted in tall cacao trees with a large increase in TCSA had the highest percentage of survival. This is also consistent with the report that cacao varieties that have a rapid increase in stem diameter during the establishment stage could better withstand dry weather conditions [5]. This is probably due to their well-developed root systems that enable these cacao seedlings to obtain and utilize water during the dry season. It has been reported that plants subjected to drier conditions allocate relatively more biomass to roots than to the above ground structures, which increases a plant's ability to acquire water and eventually improves its rate of survival [39-41].

Furthermore, plant size at transplanting as estimated by TCSA could have a positive effect on seedling survival during periods of dry weather [4]. Generally, the rapid increase in TCSA from photosynthesis occurring throughout the experimental period appears favourable to survival of the cacao trees during the dry weather particularly for the treatments that have either PM alone or as part of the soil amendments. It has been reported that the abscission of leaves by cacao trees at the onset of dry weather conditions was means of survival [4]. In this experiment, it was observed that cacao trees in T2 (least increase in TCSA and high survival) compared to T1 had high abscission of leaves than $\mathrm{T} 1$ at the onset of dry weather conditions which proved valuable to survival as leaf shedding reduces water loss in dry weather. It has been observed that cacao trees that failed to shed their leaves wilted and died with their leaves intact by the end of the experimental period [4]. The majority of the surviving cacao trees in this experiment were those observed to have ceased the production of new flush leaves early in the dry season and shed most of their leaves late in the dry season.

The growth of the cacao trees in each treatment was assessed in terms of plant height and increase in TCSA over the period of the experiment. The height of cacao trees ranged from 139.2 to $177.5 \mathrm{~cm}$ among the treatments. Cacao trees supplied with 75\% SOA plus PM (T4) were significantly $(p<0.05)$ taller than the trees in the other treatments (Table 6). Cacao trees of T2 (SOA alone) which were the shortest were like $\mathrm{T} 1, \mathrm{~T} 5$, and $\mathrm{T} 6$ in height and significantly shorter than T3 and T4 cacao trees. This demonstrates that $\mathrm{T} 4$ is an appropriate combination of SOA and PM that would ensure good growth of cacao, particularly on marginal soil. The increase in TCSA ranged from 30.4 to $37.5 \mathrm{~cm}^{2}$ among the treatments. Over the 22 -month period of field growth, the fastest-growing cacao trees were those of T3, T4, and T6 with the largest increase in TCSA that was significantly $(p<0.001)$ higher than that of other treatments (Table 6). Supplying SOA alone resulted in TCSA that was significantly lower than the nonamended control. The poor growth of SOA alone cacao trees would be a result from the low uptake of $\mathrm{Mg}$ (Table 7) and low $\mathrm{Mg} / \mathrm{K}$ ratio (Table 8 ), and this $\mathrm{Mg}$ deficiency might have been exacerbated by applications of the SOA. It is known that $\mathrm{Mg}$ is at the centre of chlorophyll formation and its uptake is strongly influenced by the availability of other cations like $\mathrm{NH}^{4+}$ [42]. Hence, the application of SOA might have reduced its uptake, thereby affecting chlorophyll formation leading to poor cacao growth in SOA alone.

The low soil $\mathrm{pH}, \mathrm{OC}, \mathrm{AP}$, and exchangeable $\mathrm{Ca}$ in baseline soil (Table 4) would suggest that the poor growth of these cacao trees in $\mathrm{T} 1$ and $\mathrm{T} 2$ was a result of low availability and/or uptake of $\mathrm{P}$ and $\mathrm{Ca}$ and that this deficiency was exacerbated by applications of the SOA used in the experiment. Although soil $\mathrm{pH}, \mathrm{OC}, \mathrm{AP}$, and exchangeable Ca were in the critically low range at the experimental site, the application of PM alone (T3) and its combination with SOA (T4-T6) improved growth. The PM amendments had a considerable role in the provision of these nutrients, either by direct decomposition of the PM or by influencing their availability through critical roles such as mineralization of organic matter. The rapid growth response of cacao trees to the PM amendments in this experiment suggests that PM stimulated processes in the labile OC pool [43], resulting in increased availability of nutrients, particularly macronutrients. The low $\mathrm{C}: \mathrm{N}$ ratio (0.9) of the PM used in the entire duration of the experiment (Table 2) and the low $\mathrm{C}: \mathrm{N}$ ratio (10) in the soil at the experimental site (Table 4) would have promoted rapid decomposition and release of nutrients from the added PM. Soil microbial populations and activity play a crucial role in nutrient availability; therefore, the addition of PM [44] may have boosted their activity for the release of nutrients into the soil. Additionally, a high proportion of soil $\mathrm{N}$, particularly in weathered tropical soils like the soil used for the experiment, occurs in an organic matter [45] and it 
TABLe 7: Leaf macronutrient contents of cacao plants in April 2017 and January 2019.

\begin{tabular}{|c|c|c|c|c|c|c|c|c|c|c|}
\hline \multirow{2}{*}{ Nutrient (\%) } & \multirow{2}{*}{ Date } & \multicolumn{6}{|c|}{ Treatments } & \multirow{2}{*}{ SED } & \multicolumn{2}{|c|}{ Normal concentrations } \\
\hline & & $\mathrm{T} 1$ & $\mathrm{~T} 2$ & $\mathrm{~T} 3$ & $\mathrm{~T} 4$ & $\mathrm{~T} 5$ & T6 & & Murray (1967) & Fahmy (1977) \\
\hline \multirow[t]{2}{*}{$\mathrm{N}$} & $I$ & 1.25 & 1.27 & 1.23 & 1.24 & 1.22 & 1.25 & 0.03 & $>2$ & $2.3-3.0$ \\
\hline & $I I$ & 1.47 & 1.88 & 2.53 & 2.57 & 2.39 & 2.46 & 0.34 & & \\
\hline \multirow[t]{2}{*}{$\mathrm{P}$} & $I$ & 0.27 & 0.28 & 0.43 & 0.39 & 0.34 & 0.40 & 0.01 & $>0.20$ & $0.16-0.30$ \\
\hline & $I I$ & 0.24 & 0.29 & 0.37 & 0.38 & 0.30 & 0.32 & 0.07 & & \\
\hline \multirow[t]{2}{*}{$\mathrm{K}$} & $I$ & 0.86 & 0.76 & 0.82 & 0.84 & 0.82 & 0.80 & 0.02 & $>2$ & $1.6-2.6$ \\
\hline & $I I$ & 0.70 & 0.52 & 0.77 & 0.83 & 0.53 & 0.58 & 0.12 & & \\
\hline \multirow[t]{2}{*}{$\mathrm{Mg}$} & $I$ & 0.51 & 0.48 & 0.55 & 0.54 & 0.42 & 0.52 & 0.02 & $>0.45$ & $0.4-1.0$ \\
\hline & II & 0.49 & 0.36 & 0.54 & 0.62 & 0.44 & 0.47 & 0.05 & & \\
\hline \multirow[t]{2}{*}{$\mathrm{Ca}$} & $I$ & 0.88 & 0.88 & 0.76 & 0.96 & 0.76 & 0.66 & 0.02 & $>0.4$ & $0.8-2.6$ \\
\hline & II & 0.88 & 0.72 & 1.30 & 1.31 & 1.19 & 1.21 & 0.24 & & \\
\hline
\end{tabular}

$\mathrm{I}=$ April 2017 sampling. $\mathrm{II}=$ January 2019 sampling. SED = standard errors of differences in means.

TABLE 8: Ratios of leaf macronutrients determined in 2019.

\begin{tabular}{lcccccc}
\hline \multirow{2}{*}{ Nutrient ratio } & \multicolumn{7}{c}{ Treatment } \\
& T1 & T2 & T3 & T4 & T5 & T6 \\
\hline $\mathrm{N} / \mathrm{P}$ & 6.17 & 6.43 & 6.81 & 6.68 & 8.06 & 7.76 \\
$\mathrm{Ca} / \mathrm{K}$ & 1.26 & 1.39 & 1.69 & 1.57 & 2.23 & 2.07 \\
$\mathrm{Ca} / \mathrm{Mg}$ & 1.80 & 2.00 & 2.40 & 2.11 & 2.70 & 2.56 \\
$\mathrm{Mg} / \mathrm{K}$ & 0.70 & 0.69 & 0.70 & 0.74 & 0.83 & 0.81 \\
\hline
\end{tabular}

was obvious that the PM amendments either alone or in combination with SOA enhanced the availability of $\mathrm{N}$, enabling greater growth. Likewise, overall uptake of other macronutrients was increased by organic amendment (T3-T6), resulting in larger cacao trees, but such an increase did not occur following amendment with SOA alone (T2), despite the increased supply of readily available $\mathrm{N}$.

3.4. Nutrient Uptake and Leaf Nutrient Ratios. Cacao plant $\mathrm{N}$ uptake in 2017 was unaffected by the soil amendments since leaf $\mathrm{N}$ concentrations were similar in all treatments (Table 7). However, the uptake of $\mathrm{N}$ by cacao plants was significantly different $(p<0.05)$ among treatments in 2019, with the highest $\mathrm{N}$ concentration in T4 and the least in T1 (nonamended control). Nitrogen leaf concentrations were below normal concentrations in the younger plants (2017) in all the treatments. For older plants (2019), except for T1 and $\mathrm{T} 2$, the leaf $\mathrm{N}$ concentrations of cacao plants in PM alone and its combination with SOA-treated plots were higher than the normal levels reported in the cacao plants $[46,47]$. This is an indication that uptake rates of $\mathrm{N}$ were probably affected by the PM amendments since leaf $\mathrm{N}$ concentrations were higher in these treatments. PM used for this experiment had high OC and N content; therefore, its application might have directly increased soil inorganic $\mathrm{N}$ from mineralization of organic $\mathrm{N}$ in PM by soil microorganisms and creating good soil conditions for $\mathrm{N}$ uptake by the cacao trees. It is apparent that the PM amendments enhanced the availability of $\mathrm{N}$, enabling greater growth.

Leaf concentrations of $\mathrm{P}$ were within the normal concentration reported for cacao trees $[46,47]$ and differed significantly in year one but did not differ significantly in year two regardless of the soil treatment (Table 7). However,
$\mathrm{P}$ concentrations in cacao leaves were higher in PM alone and its combinations with SOA than in the nonamended control and sole SOA treatments in both years. Among the treatments, $\mathrm{T} 4$ had the highest leaf $\mathrm{P}$ concentration (Table 7). The higher levels of $\mathrm{P}$ concentration in leaves generally under PM-treated plots could be due to increasing availability of $\mathrm{P}$ as facilitated by the addition of organic matter in the form of PM resulting in solubilizing insoluble $\mathrm{P}$ to supply soluble P for uptake by cacao trees. The application of organic manures helps in reducing the fixation of applied $\mathrm{P}$ and thereby causing an increase in its availability to the crop, resulting in an increased phosphate concentration in the leaf [48]. The results of this study also corroborated the report that leaf $\mathrm{P}$ concentration of citrus increased with integrated use of organic and inorganic fertilizers [49].

Potassium concentrations in leaves were below the normal concentration reported for cacao trees [46, 47]. Leaf concentrations of $\mathrm{K}$ in year one were significantly different but were not significantly different in year two (Table 7). The low leaf $\mathrm{K}$ concentrations in the second year could presumably be due to the fact that soil $\mathrm{K}$ became more limiting as the plants age. The leaf concentrations of $\mathrm{K}$ in the second year of the nonamended control were compared favourably with the amended plots especially PM-amended plots. This is an indication that the leaf $\mathrm{K}$ concentrations were mainly unaffected by the soil treatments and the plants did not take up enough $\mathrm{K}$ to ensure normal leaf concentrations. However, T4 had the highest $\mathrm{K}$ concentration and $\mathrm{T} 2$ the least $\mathrm{K}$ concentration among the soil treatments. The leaf $\mathrm{Mg}$ and $\mathrm{Ca}$ concentrations were generally above the normal range reported for cacao trees [46, 47]. Generally, leaf concentrations of $\mathrm{Mg}$ in year one except for T4 and T5 were high in all the soil treatments (Table 7). Magnesium concentrations in leaf of cacao plants were significantly different $(p<0.05)$ in the first year but not in the second year among the soil treatments. Cacao trees of T4 had significantly higher leaf $\mathrm{Mg}$ concentration, whereas $\mathrm{T} 2$ had the lowest in the second year. Like $\mathrm{Mg}$, Ca concentration in cacao leaves in the first year was significantly different $(p<0.05)$ among the soil treatments but not in the second year. Calcium concentrations in leaves were above the normal concentration reported for cacao trees [46]. Leaves of T4 cacao trees had the highest $\mathrm{Ca}$ content in both years, whereas $\mathrm{T} 3$ and $\mathrm{T} 2 \mathrm{had}$ 
the least $\mathrm{Ca}$ content in year one and year two, respectively. Generally, the results indicated a high nutrient content in cacao leaves of T4 compared to other treatments. This could be explained by the better growth of cacao trees in T4, which implies that the plants were able to mobilize these nutrients from the soil.

Low leaf N/P ratios in the nonamended control and sole SOA cacao trees were observed; however, there was somewhat an increase in leaf $\mathrm{N} / \mathrm{P}$ ratio when soils were amended with PM (T3 to T6). This suggests that the $\mathrm{N}$ uptake rate by cacao trees was not the most limiting factor in the soil at the experimental site. The leaf $\mathrm{Ca} / \mathrm{K}$ and $\mathrm{Ca} / \mathrm{Mg}$ ratios were low in the nonamended control that is 1.26 and 1.80 , respectively. The sole SOA treatments had 1.39 and 2.00 leaf $\mathrm{Ca} / \mathrm{K}$ and $\mathrm{Ca} / \mathrm{Mg}$ ratios, respectively. But all treatments with $\mathrm{PM}$ increased both leaf $\mathrm{Ca} / \mathrm{K}$ and $\mathrm{Ca} / \mathrm{Mg}$ ratios (Table 8). Applying SOA in combination with PM (T3 to T6) seemed to have a synergistic effect, as leaf $\mathrm{Ca} / \mathrm{K}, \mathrm{Ca} /$ $\mathrm{Mg}$, and $\mathrm{Mg} / \mathrm{K}$ ratios increased greatly under this combination.

Magnesium could be a limiting factor to growth because the low leaf $\mathrm{Mg} / \mathrm{K}$ ratio observed in nonamended control cacao trees was further lowered because of the application of SOA alone, while the leaf $\mathrm{Mg} / \mathrm{K}$ ratio increased with $\mathrm{PM}$ supplied either alone or in combination with SOA.

\section{Conclusion}

This study has shown that integrated nutrient amendment of marginal soils will greatly benefit the nutrition of cacao trees. Despite increasing the readily available $\mathrm{N}$ with SOA, application of SOA alone resulted in cacao trees with smaller TCSA than the other treatments that were amended with PM. Obviously, organic matter played a role in promoting the uptake of nutrients, resulting in generally higher TCSA and highly improved survival of cacao trees in treatments with PM amendments. The possibility and benefit of supplying nutrients to cacao trees by combining PM (organic fertilizer) and SOA (inorganic fertilizer) have been clearly shown in this study. The best growth and survival rate were recorded for $\mathrm{T} 4$ (75\% recommended dosage of SOA + PM). From its preeminence over the other treatments in growth and survival, T4 would ensure improved establishment success and more vigorous growth of cacao trees in marginal soils.

\section{Data Availability}

The data used to support the findings of this study are available from the corresponding author upon request.

\section{Conflicts of Interest}

The authors declare that they have no conflicts of interest regarding the publication of this study.

\section{Acknowledgments}

The authors are grateful for the immense technical support of the staff of the Soil Science Division of the Cocoa Research
Institute of Ghana in carrying out this research. The work is published with the permission of the Executive Director of Cocoa Research Institute of Ghana as manuscript number CRIG/01/2020/053/004.

\section{References}

[1] Institute of Statistical, Social and Economic Research (ISSER), State of the Ghanaian Economy 2014, ISSER, University of Ghana, Legon, Accra, Ghana, 2015, http://isser.edu.gh/ images/Publication_files/SGER2014_Overview.pdf.

[2] F. Baah, "Harnessing farmer associations as channels for enhancing management of cocoa holdings in Ghana," Scientific Research and Essay, vol. 3, pp. 395-400, 2008.

[3] F. K. Padi and A. Ofori, "Cacao seed purity and genotype influence on seedling growth under Peasant-Farmer conditions in Ghana," Journal of Crop Improvement, vol. 30, no. 5, pp. 493-515, 2016.

[4] F. K. Padi, P. Adu-Gyamfi, A. Akpertey, A. Arthur, and A. Ofori, "Differential response of cocoa (Theobroma cacao) families to field establishment stress," Plant Breeding, vol. 132, no. 2, pp. 229-236, 2013.

[5] A. Ofori, F. K. Padi, K. Acheampong, and S. Lowor, "Genetic variation and relationship of traits related to drought tolerance in cacao (Theobroma cacao L.) under shade and no shade conditions in Ghana," Euphytica, vol. 2015, pp. 411-421, 2015.

[6] Y. Ahenkorah, B. J. Halm, M. R. Appiah, and G. S. Akrofi, "Fertilizer use on cocoa rehabilitation projects in Ghana," in Proceeding of the 8th International Cocoa Research Conference, pp. 165-170, Cartagena, Colombia, October 1982.

[7] S. Mulia, P. J. Mcmahon, A. Purwantara et al., "Effect of organic and inorganic amendments on productivity of cocoa on a marginal soil in Sulawesi, Indonesia," Experimental Agriculture, vol. 55, no. 1, pp. 1-20, 2017.

[8] M. R. Appiah, K. Ofori-Frimpong, A. A. Afrifa, and E. G. Asante, "Prospects of fertilizer use in the cocoa industry in Ghana," Proceeding of Soil Science Society of Ghana, Kumasi, vol. 14, no. 15, Ghana, 1997.

[9] K. Opoku-Ameyaw, F. Baah, E. Gyedu-Akoto et al., Cocoa Manual: A Source Book for Sustainable Cocoa Production, , pp. 28-29, " Cocoa Research Institute of Ghana, 2010.

[10] I. Macit, A. Koc, S. Guler, and I. Deligoz, "Yield, quality and nutritional status of organically and conventionally grown strawberry cultivars," Asian Journal of Plant Sciences, vol. 6, no. 7, pp. 1131-1136, 2007.

[11] M. K. Abbasi, F. Hussain, and S. A. Majid, "Changes in the behaviour and physical and chemical characteristics of soil after adding Populus euramericana leaves," Science Technology Development, vol. 21, pp. 15-19, 2002.

[12] S. N. Dauda, F. A. Ajayi, and E. Ndor, "Growth and yield of watermelon (Citrullus lanatus) as affected by poultry manure application," Journal of Agriculture and Social Science, vol. 4, pp. 121-124, 2008.

[13] S. S. Shivputra, C. P. Patil, G. S. K. Swamy, and P. B. Patil, "Cumulative effect of VAM fungi and vermicompost on nitrogen, phosphorus, potassium and chlorophyll content of papaya leaf," Mycorrhiza News, vol. 16, no. 2, pp. 15-16, 2004.

[14] S. Bokhtiar and K. Sakurai, "Effects of organic manure and chemical fertilizer on soil fertility and productivity of plant and ratoon crops of sugarcane," Archives of Agronomy and Soil Science, vol. 51, no. 3, pp. 325-334, 2005.

[15] H. Brammer, "Soils of Ghana," in Agriculture and Land Use of Ghana,", J. B. Wills, Ed., pp. 88-126, Oxford Univ. Press, London, 1962. 
[16] FAO/UNESCO, Soil Map of the World Revised Legend, Food and Agriculture Organization, Rome, 1990.

[17] S. V. Adu and R. D. Asiamah, "Soils of the Ayensu-Densu Basin," Memoir No. 9, Soil Research Institute/Council for Scientific and Industrial Research, Kumasi, Ghana, 1992.

[18] H. Toxopeus, "Botany, Types and Populations," in Cacao., G. A. R. Wood and R. A. Lass, Eds., pp. 11-37, Longman, London; New York, 4th edition, 1985.

[19] A. E. Hartemink, "Nutrient stocks, nutrient cycling, and soil changes in cocoa ecosystems: a review," Advances in Agronomy, vol. 86, pp. 227-253, 2005.

[20] J. G. de Geus, Fertilizer Guide for the Tropics and Subtropics, Centre d'Etude de l'Azonte, Zurich, 1973.

[21] G. J. Bouyoucos, "Hydrometer method improved for making particle size analyses of soils 1," Agronomy Journal, vol. 54, no. 5, pp. 464-465, 1962.

[22] E. O. McLean, "Soil pH and lime requirement," in Methods of Soil Analysis. Part 2. Chemical and Microbiological Properties, A. L. Page, R. H. Miller, and D. R. Keeney, Eds., American Society of Agronomy and Soil Science Society of America, Madison, Wisconsin USA, Second Edition, 1982.

[23] A. Walkley and I. A. Black, "An examination of the Degtjareff method for determining organic carbon in soils: effect of variations in digestion conditions and of inorganic soil constituents," Soil Science, vol. 63, pp. 251-263, 1934.

[24] J. M. Bremner and C. S. Mulvaney, "Nitrogen-total," in Methods of Soil Analysis. Part 2. Chemical and Microbiological Properties," Agronomy 9, A. L. Page and R. H. Miller, Eds., pp. 595-624, American Society of Agronomy, Soil Science Society of America, Madison, Wisconsin, 2nd edition, 1982.

[25] A. Mehlich, "Mehlich 3 soil test extractant: a modification of Mehlich 2 extractant," Communications in Soil Science and Plant Analysis, vol. 15, no. 12, pp. 1409-1416, 1984.

[26] J. J. Hanway and H. Heidel, "Soil analysis methods as used in Iowa State College soil testing laboratory," Iowa State College of Agriculture, USA," Bulletin, vol. 57, pp. 1-131, 1952.

[27] AOAC, Official Methods, Association of Official Analytical Chemists, Washington, DC, 12th edition, 1990.

[28] P. N. Nelson, M. J. Webb, S. Berthelsen et al., "Nutritional status of cocoa in Papua New Guinea," Better Crops with Plant Food, vol. 95, pp. 18-20, 2011.

[29] C. Fidelis and B. K. Rajashekhar Rao, "Enriched cocoa pod composts and their fertilizing effects on hybrid cocoa seedlings," International Journal of Recycling of Organic Waste in Agriculture, vol. 6, no. 2, pp. 99-106, 2017.

[30] V. C. Baligar and N. K. Fageria, "Soil aluminum effects on growth and nutrition of cacao," Soil Science and Plant Nutrition, vol. 51, no. 5, pp. 709-713, 2005.

[31] H. Marschner, Mineral Nutrition of Higher Plants, Academic Press, London, UK, 1995.

[32] N. V. Hue, "Alleviating soil acidity with crop residues," Soil Science, vol. 176, no. 10, pp. 543-549, 2011.

[33] P. P. Singh, R. Pawar, and R. Meena, "Response of integrated nutrient management on yield and chemical properties of soil under rice-wheat cropping system," International Journal of Chemical Studies, vol. 5, no. 2, pp. 366-369, 2017.

[34] D. D. Patra, M. Anwar, and S. Chand, "Integrated nutrient management and waste recycling for restoring soil fertility and productivity in Japanese mint and mustard sequence in Uttar Pradesh, India," Agriculture, Ecosystems \& Environment, vol. 80, no. 3, pp. 267-275, 2000.

[35] L. K. Opeke and H. Toxopeus, "Preliminary studies on the yield and establishment of WACRI Series I and II cacao varieties in Western Nigeria," Nigerian Agricultural Journal, vol. 4, pp. 22-27, 1967.

[36] R. Condit, S. P. Hubbell, and R. B. Foster, "Mortality rates of 205 neotropical tree and shrub species and the impact of a severe drought," Ecological Monographs, vol. 65, no. 4, pp. 419-439, 1995.

[37] K. Acheampong, P. Hadley, A. Daymond, and P. AduYeboah, "The influence of shade and organic fertilizer treatments on the physiology and establishment of Theobroma cacao clones," American Journal of Experimental Agriculture, vol. 6, no. 6, pp. 347-360, 2015.

[38] W. V. Hutcheon, Breeding for tolerance of exposure and the ability to respond to increased radiation, pp. 203-204, Cocoa Research Institute of Ghana, Ghana, 1973.

[39] T. Smith and M. Huston, "A theory of the spatial and temporal dynamics of plant communities," Vegetatio, vol. 83, no. 1-2, pp. 49-69, 1989.

[40] F. Lloret, C. Casanovas, and J. Peñuelas, "Seedling survival of Mediterranean shrubland species in relation to root:shoot ratio, seed size and water and nitrogen use," Functional Ecology, vol. 13, no. 2, pp. 210-216, 1999.

[41] M. S. Heschel, S. E. Sultan, S. Glover, and D. Sloan, "Population differentiation and plastic responses to drought stress in the generalist annual Polygonum persicaria," International Journal of Plant Sciences, vol. 165, no. 5, pp. 817-824, 2004.

[42] A. R. Dechen, Q. A. C. Carmello, F. A. Monteiro, and R. C. Nogueirol, "Role of magnesium in food production: an overview," Crop and Pasture Science, vol. 66, no. 12, pp. 1213-1218, 2015.

[43] P. L. Woomer, A. Martin, A. Albrecht, D. V. S. Resck, and H. W. Scharpenseel, "The importance and management of soil organic matter in the tropics," in The Biological Management of Tropical Soil Fertility, P. L. Woomer and M. J. Swift, Eds., pp. 47-80, Wiley-Sayce Publications, Chichester, UK, 1994.

[44] M. Burger and L. E. Jackson, "Microbial immobilization of ammonium and nitrate in relation to ammonification and nitrification rates in organic and conventional cropping systems," Soil Biology and Biochemistry, vol. 35, no. 1, pp. 29-36, 2003.

[45] C. Steiner, W. G. Teixeira, J. Lehmann et al., "Long term effects of manure, charcoal and mineral fertilization on crop production and fertility on a highly weathered Central Amazonian upland soil," Plant and Soil, vol. 291, no. 1-2, pp. 275-290, 2007.

[46] D. B. Murray, "Leaf analysis applied to cocoa," Cocoa Growers' Bulletin, vol. 9, pp. 25-31, 1967.

[47] F. N. Fahmy, "Soil and leaf analyses in relation to the nutrition of tree crops in Papua New Guinea,", in Proceedings of the Conference on Classification and Management of Tropical Soils.

[48] S. L. Dhote and M. P. Kawthalkar, "Effect of application of chopped Lucerne on productivity of cabbage," Journal of Soils and Crops, vol. 6, pp. 73-77, 1996.

[49] C. Singh and B. B. Sharma, "Leaf nutrient composition of sweet orange as affected by combined use of bio and chemical fertilizer," South Indian Horticulture, vol. 41, pp. 131-134, 1993. 